\title{
Chemical Constituents of Cymbocarpum erythraeum (DC.) Boiss., and Evaluation of Its Anti-Helicobacter pylori Activity
}

\section{Cymbocarpum erythraeum (DC.) Boiss.'in Kimyasal Bileşikleri ve Helicobacter pylori'ye Karşı Etkisi}

\author{
(D) Samaneh HEIDARI', (D) Azadeh MANAYI², (D) Soodabeh SAEIDNIA², (D) Hossein MIGHANI', (D) Hamid Reza MONSEF ESFAHANI ${ }^{3}$, \\ (D) Ahmad Reza GOHARI²*, (D) William N SETZER ${ }^{4}$ \\ 'Golestan University, Faculty of Science, Department of Chemistry, Golestan, Iran \\ ${ }^{2}$ Tehran University of Medical Sciences, Faculty of Pharmacy, Medicinal Plants Research Center, Tehran, Iran \\ ${ }^{3}$ Tehran University of Medical Sciences, Faculty of Pharmacy, Department of Pharmacognosy, Tehran, Iran \\ ${ }^{4}$ University of Alabama in Huntsville, Faculty of College of Science, Departments of Chemistry, Huntsville, USA
}

\section{ABSTRACT}

Objective: Cymbocarpum erythraeum (Apiaceae) is an endemic species in Iran. Up to now, there have been no phytochemical and biological investigations on this species. Therefore, isolation of the main secondary metabolites of the plant along with its anti- $H$. pylori activity have been considered in this paper.

Materials and Methods: The dried parts of the plant were extracted with different solvents using solvent percolation and the antibacterial activity of the extracts evaluated by the disk diffusion method. Four compounds were isolated using different column chromatography methods.

Results: The compounds were identified by proton nuclear magnetic resonance and carbon-13 nuclear magnetic resonance as isoquercetin (1), rutin (2), $\beta$-sitosterol (3) and 2-decenol (4).

Conclusion: Anti-H. pylori evaluation of the extracts and isolated compounds against three clinical isolates of $H$. pylori revealed that hexane extract of the plant inhibited all H. pylori strains.

Key words: Apiaceae, C. erythraeum, chromatography, disk diffusion, H. pylori

öz

Amaç: Cymbocarpum erythraeum (Apiaceae) İran'a endemik bir türdür. Bu zamana kadar, bu tür üzerinde herhangi bir fitokimyasal ve biyolojik aktivite çalışmasına rastlanmamıştır. Bu nedenle, bu çalışmada, bitkinin ana sekonder metabolitlerinin ve Helicobacter pylori'ye karşı etkisinin araștırılması amaçlanmıștır.

Gereç ve Yöntemler: Kurutulmuş bitki kısımları perkolasyon yöntemi ile farklı çözücüler kullanılarak ekstre edilmiş ve ekstrelerin antibakteriyel etkisi disk difüzyon yöntemiyle değerlendirilmiştir. Farklı kolon kromatografisi yöntemleri kullanılarak dört bileșik izole edilmiştir.

Bulgular: Bileșiklerin yapıları, proton nükleer manyetik rezonans ve karbon-13 nükleer manyetik rezonans tekniği ile izokersetin (1), rutin (2), $\beta$-sitosterol (3) ve 2-dekenol (4) olarak belirlenmiştir.

Sonuç: Ekstrelerin ve izole edilen bileşiklerin üç H. pylori klinik izolatına karşı etkilerinin değerlendirildiği bu çalışmada, bitkinin hekzan ekstresinin tüm H. pylori suşlarını ihibe ettiği tespit edilmiştir.

Anahtar kelimeler: Apiaceae, C. erythraeum, kromatografi, disk difüzyon, H. pylori

*Correspondence: E-mail: a_goharii@tums.ac.ir, Phone: +9821-64121202 ORCID-ID: orcid.org/0000-0001-9071-1663

Received: 16.04.2017, Accepted: 27.07.2017

-Turk J Pharm Sci, Published by Galenos Publishing House. 


\section{INTRODUCTION}

Cymbocarpum is represented in Iran by three species that occur naturally in the wild, including Cymbocarpum marginatum, Cymbocarpum erythraeum, and Cymbocarpum anethoides.,2 The essential oils had been obtained from these three species of Cymbocarpum from Iran and analyzed indicating that the oils of all three plants were rich in aliphatic aldehydes. Furthermore, the oil of $C$. erythraeum, with main constituent (E)-2-decenal (52.22\%), showed larvicidal activity. ${ }^{3}$ The main components of the essential oils of the fruits and herbal parts of Cymbocarpum wiedemannii were found to be aliphatic aldehydes and aliphatic acids. ${ }^{4}$

A major cause of bacterial gastrointestinal infections is Helicobacter pylori. In fact, $H$. pylori has been designated as a class I carcinogen by World Health Organization and its eradication has been reported to be beneficial in preventing gastric disorders specially ulcer and cancer. ${ }^{5}$ Given the extensive treatment with antibiotics for decades, the failure rates due to antimicrobial resistance range from $20 \%$ to $40 \%$ and the eradication failure rate remains as high as 5-20\%.6-8 Regarding the previous study which indicated that methanol extract of the plant showed antibacterial activity ${ }^{9}$ and anti- $H$. pylori activity of some flavonoids ${ }^{10}$ the present study was designed to evaluate anti-H. pylori property of the plant extracts and its flavonoids.

\section{MATERIALS AND METHODS}

\section{Plant material}

The flowering aerial parts of $C$. erythraeum were collected from the East Azerbaijan province (June 2010) with voucher No. 214 at the Herbarium of Institute of Medicinal Plants, Iranian Academic Centre for Education, Culture and Research, Karaj, Iran.

\section{General}

Silica gel (70-230 mesh, F254 pre-coated plates) (Merck, Germany), reverse phase silica gel 90 (RP-18C; Fluka, Switzerland) and Sephadex LH-20 (Fluka, Switzerland) were used for isolation of compounds. Semi-preparative highperformance liquid chromatography [HPLC (RP-18C; Knauer, Germany)] and medium-pressure liquid chromatography [MPLC (Silica gel, 230-400 mesh; Butchi, Switzerland)] were used for more purification. Nuclear magnetic resonance (NMR) experiments were performed on Bruker (Billerica, USA) DRX 500 instrument [500 MHz for proton NMR ('H-NMR), $125 \mathrm{MHz}$ for carbon-13 $\left.\left({ }^{13} \mathrm{C}-\mathrm{NMR}\right)\right]$ with tetramethylsilane as an internal standard. Ultraviolet (UV) spectra were measured on Optizen (Daejeon, Korea) model 2021 UV plus. All solvents were distilled before use.

\section{Isolation procedure}

Dried aerial parts of C. erythraeum (500 g) were extracted with hexane, methanol and water-methanol (1:1) using the solvent percolation method at room temperature. Extracts were concentrated to obtain 11, $80,34 \mathrm{~g}$ of hexane, methanol and methanol-water (1:1) extracts, respectively. The methanol extract was further partitioned by petroleum ether, butanol and water. The butanol fraction ( $8 \mathrm{~g}$ ) was subjected to Sephadex $\mathrm{LH}_{20}$ column to afford $\mathrm{B}_{\mathrm{A}}-\mathrm{B}_{\mathrm{E}}$ fractions and those suspected to contain flavonoids under UV light were loaded on another column for more purification. A sub-fractions $\left(B_{A}: 3980 \mathrm{mg}, B_{B}\right.$ : $84 \mathrm{mg}$ ) were loaded on Sephadex $\mathrm{LH}_{20}$ column with methanol as eluent to obtain compounds $1(8.4 \mathrm{mg})$ and $3(12 \mathrm{mg})$. The other sub-fraction $\left(B_{c}: 106.6 \mathrm{mg}\right.$ ) was injected to HPLC (RP$18 \mathrm{C})$ eluted with different percentage of methanol-water (2:3, $1: 1$, and $3: 2$ ) to yield compound 2 ( $27 \mathrm{mg}$ ). In addition, the hexane extract was injected to MPLC (normal phase silica gel column) eluted with hexane-chloroform (4:1 and 0:1) to give 12 primary fractions $\left(\mathrm{H}_{\mathrm{A}}-\mathrm{H}_{\mathrm{L}}\right)$. One fraction $\left(\mathrm{H}_{\mathrm{J}}\right.$ : $\left.239 \mathrm{mg}\right)$ was subjected to Sephadex $\mathrm{LH}_{20}$ column with chloroform-ethyl acetate-methanol (1:1:1) as eluent to provide pure compound 4 (4.1 mg).

\section{Anti-H. pylori assay}

Clinical $H$. pylori $\left(\mathrm{HP}_{1}, \mathrm{HP}_{2}\right.$, and $\left.\mathrm{HP}_{3}\right)$ strains were used to determine antimicrobial susceptibility following previously published protocols using the disk diffusion method. ${ }^{11,12}$ Serial dilutions of the test samples were made in dimethyl sulfoxide (DMSO). Suspensions of bacteria in normal saline were prepared with the turbidity of McFarland standard No. $2\left(6 \times 10^{8}\right.$ cell $/ \mathrm{mL}$ ). Plates of non-selective blood agar were inoculated with $100 \mu \mathrm{L}$ of each bacterial suspension and allowed to dry at room temperature. Ten $\mu \mathrm{L}$ of test samples was introduced into a sterile blank disks and deposited on the surface of the inoculated plates. Negative and positive control included blank disks impregnated with $10 \mu \mathrm{L}$ of DMSO and amoxicillin $(1 \mu \mathrm{g} / \mathrm{mL})$, respectively. Plates were incubated at $37^{\circ} \mathrm{C}$ under microaerobic conditions and examined after 3-5 days. The mean inhibition zone diameters $(I Z D) \pm$ standard deviation were recorded.

\section{RESULTS AND DISCUSSION}

The isolated compounds from aerial parts of $C$. erythraeum were identified as isoquercetin (1), rutin (2), ${ }^{13,14}$ along with $\beta$-sitosterol (3), ${ }^{15-17}$ and 2-decenol (4) based on the spectroscopic data $\left({ }^{1} \mathrm{H}-\mathrm{NMR},{ }^{13} \mathrm{C}-\mathrm{NMR}\right)$ and compared to the pertinent spectroscopic data in previously published literature (Figure 1). ${ }^{9}$

To the best of our knowledge, this is the first report on the isolation and elucidation of secondary metabolites of $C$.
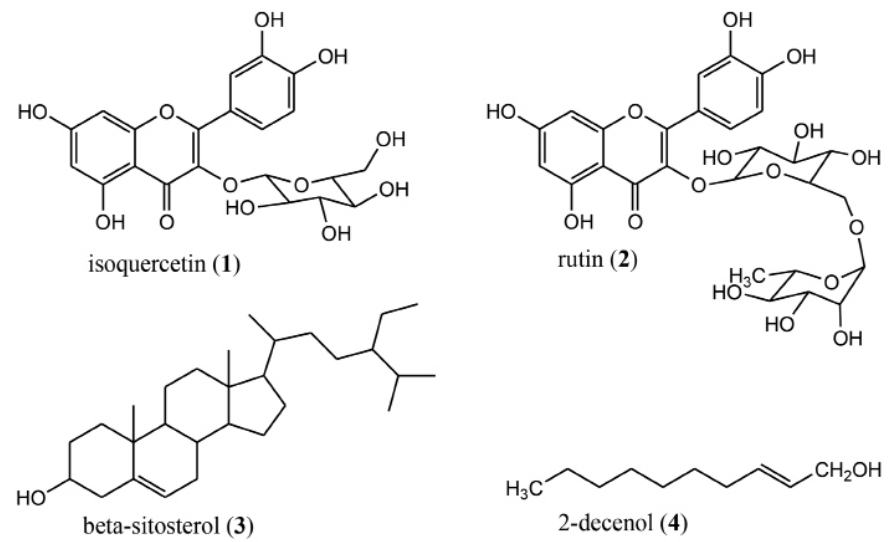

Figure 1. Chemical structures of the isolated compounds from C. erythraeum 
Table 1. Inhibition zone diameters \pm standard deviation of some active extracts of $C$. erythraeum against clinical isolates of $H$. pylori

\begin{tabular}{|c|c|c|c|c|c|c|c|c|c|c|c|c|}
\hline \multirow[t]{2}{*}{ Samples } & \multicolumn{3}{|l|}{1 Conc. } & \multicolumn{3}{|l|}{ 1/2 Conc. } & \multicolumn{3}{|l|}{ 1/4 Conc. } & \multicolumn{3}{|c|}{ 1/8 Conc. } \\
\hline & HP1 & HP2 & HP3 & HP1 & HP2 & HP3 & HP1 & HP2 & HP3 & HP1 & HP2 & HP3 \\
\hline Methanol $^{2}$ & - & - & $14 \pm 0.04$ & - & - & $13 \pm 0.04$ & - & - & $10 \pm 0.02$ & - & - & - \\
\hline $\mathrm{PE}^{3}$ & - & - & $15 \pm 0.02$ & - & - & $12 \pm 0.03$ & - & - & $10 \pm 0.03$ & - & - & - \\
\hline
\end{tabular}

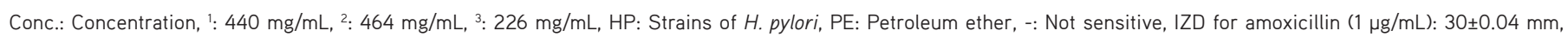
SD: Standard deviation

erythraeum and its anti-H. pylori activity. The susceptibility of the tested bacteria were different related to the extracts and $\mathrm{HP}_{3}$ was the most susceptible strain. The IZD of the effective test samples against $H$. pylori are summarized in (Table 1 ). The growth of all bacterial strains were suppressed by amoxicillin $(1 \mu \mathrm{g} / \mathrm{mL})$ with IZD of $30 \pm 0.04 \mathrm{~mm}$, while DMSO showed no inhibitory activity toward the tested organisms. Methanol (464 mg/mL) and petroleum ether $(226 \mathrm{mg} / \mathrm{mL}$ ) extracts had inhibited one of the clinical isolates of $\mathrm{H}$. pylori $\left(\mathrm{HP}_{3}\right)$ with IZD of $14 \pm 0.04$ and $15 \pm 0.02 \mathrm{~mm}$, respectively, while compounds 1 $(16 \mathrm{mg} / \mathrm{mL}), 2(14 \mathrm{mg} / \mathrm{mL})$ and the flavonoid fraction $(138 \mathrm{mg} /$ $\mathrm{mL}$ ), along with other extracts were not effective against the isolated strains.

In a previous study, rutin isolated from Gardenia jasminoides exhibited antibacterial activity toward $H$. pylori, however this present study showed the compound not to be active against the isolated strains. ${ }^{18}$ Additionally, some flavonoids are known to be antibacterial agents. ${ }^{19}$ For example, the flavonoid-rich extract of Glycyrrhiza glabra inhibited $H$. pylori growth by inhibition of protein synthesis, DNA gyrase and dihydrofolate reductase ${ }^{10}$, while the flavonoid fraction of $C$. erythraeum was not active against examined strains, which may be presumably due to the difference in the flavonoid constituents of the plants and/or the susceptibility of bacteria. Whereas in this study, the hexane extract of the plant mainly inhibited the $H$. pylori strains attributed to the presence of non-polar compounds. It was reported that essential oil of $C$. erythraeum, which was rich in (E)-2-decenal (52.22\%), was biologically active and exhibited larvicidal activity. ${ }^{3}$ In the present study, the alcoholic compound 2-decenol (4), which was isolated from hexane fraction, is likely to be one of the active constituents of this fraction as well as other constituents in this fraction. The mediumchain-length alcohol decanol, from Coriandrum sativum oil, showed antibacterial activity especially against Gram-positive strains. ${ }^{20,21}$ As a matter of fact, the relatively polar substances such as flavonoids and other polar fractions are not generally able to effectively prevent the bacterium growth, suggesting that the anti-H. pylori activity of this plant can be largely attributed to other non-polar secondary metabolites.

Conflict of Interest: No conflict of interest was declared by the authors.

\section{REFERENCES}

1. Ajani Y, Mojab F, Tabatabaii S, Ramazan-Pour B. Analysis of the essential oils from 3 species of Cymbocarpum (Apiaceae) from Iran. Res Pharm Sci. 2012;7:s708.

2. Ajany Y. Studied taxonomic genus, Cymbocarpum, Diplotaenia, Johrenia, Dorema haussknechtia, Azilia, Opopanax, Smyrniopsis of Umbelliferus Iran; Tehran University; 2004.

3. Aksakal Ö, Uysal H, Çolak DA, Mete E. Inhibition effects of essential oil of Cymbocarpum erythraeum (Dc.) Boiss., on percentage of survival from larvae to adult in Drosophila melanogaster and its chemical composition. MAKÜ FEBED. 2012;3:32-36.

4. Baser KHC, Özek T, Vural M. Essential Oil of Cymbocarpum wiedemannii Boiss. J Essent Oil Res. 1999;11:679-680.

5. Zaidi SF, Muhammad JS, Shahryar S, Usmanghani K, Gilani AH, Jafri W, Sugiyama T. Anti-inflammatory and cytoprotective effects of selected Pakistani medicinal plants in Helicobacter pylori-infected gastric epithelial cells. J Ethnopharmacol. 2012;141:403-410.

6. Li Y, Xu C, Zhang Q, Liu JY, Tan RX. In vitro anti-Helicobacter pylori action of 30 Chinese herbal medicines used to treat ulcer diseases. $J$ Ethnopharmacol. 2005;98:329-333.

7. Lien HM, Wang CY, Chang HY, Huang CL, Peng MT, Sing YT, Chen CC, Lai $\mathrm{CH}$. Bioevaluation of Anisomeles indica extracts and their inhibitory effects on Helicobacter pylori-mediated inflammation. J Ethnopharmacol. 2013;145:397-401

8. Zhang $X Q$, Gu HM, Li XZ, Xu ZN, Chen YS, Li Y. Anti-Helicobacter pylori compounds from the ethanol extracts of Geranium wilfordii. J Ethnopharmacol. 2013;147:204-207.

9. Ajani Y, Mojab F, Hajiaghaii R, Taghizadeh F, Jamalifar H. Assaying of volatile oil components and antimicrobial effects of methanolic extract of it in Cymbocarpum erythraeum (DC.) Boiss and C anethoides DC; 2012.

10. Asha MK, Debraj D, Prashanth D, Edwin JR, Srikanth HS, Muruganantham N, Dethe SM, Anirban B, Jaya B, Deepak M, Agarwal A. In vitro antiHelicobacter pylori activity of a flavonoid rich extract of Glycyrrhiza glabra and its probable mechanisms of action. J Ethnopharmacol. 2013;145:581586.

11. Manayi A, Khanavi M, Saeidnia S, Azizi E, Mahmoodpour MR, Vafi F, Malmir M, Siavashi F, Hadjiakhoondi A. Biological activity and microscopic characterization of Lythrum salicaria L. Daru. 2013;21:61.

12. Siavoshi F, Saniee P, Latifi-Navid S, Massarrat S, Sheykholeslami A. Increase in resistance rates of $H$. pylori isolates to metronidazole and tetracycline--comparison of three 3-year studies. Arch Iran Med. 2010;13:177-187.

13. Gohari A, Saeidnia S, Shahverdi A, Yassa N, Malmir M, Mollazade K, Naghinejad AR. Phytochemistry and antimicrobial compounds of Hymenocrater calycinus. Eur Asia J BioSci. 2009;3:64-68. 
14. Jafari S, Saeidnia S, Hajimehdipoor H, Ardekani MR, Faramarzi MA, Hadjiakhoondi A, Khanavi M. Cytotoxic evaluation of Melia azedarach in comparison with, Azadirachta indica and its phytochemical investigation. Daru. 2013;21:37.

15. Saeidnia S, Ghamarinia M, Gohari AR, Shakeri A. Terpenes from the root of Salvia hypoleuca Benth. Daru. 2012;20:66.

16. Saeidnia S, Nourbakhsh MS, Gohari AR, Davood A. Isolation and identification of the main compounds of Satureja sahendica Bornm. Aust J Basic Appl Sci. 2011;5:1450-1453.

17. Saeidnia S, Gohari AR, Malmir M, Moradi-Afrapoli F, Ajani Y. Tryptophan and sterols from Salvia limbata. J Med Plants. 2011;10:41-44.
18. Lee JH, Kang KJ, Lee YM, Kim PN, Jeong CS. Effects of Gardenia jasminoides Ellis ethanol extract and its constituents on anti-gastritis and anti-gastric cancer cells. Planta Med. 2008;74:289.

19. Sahreen S, Khan MR, Khan RA, Shah NA. Estimation of flavoniods, antimicrobial, antitumor and anticancer activity of Carissa opaca fruits. BMC Complement Altern Med. 2013;13:372.

20. Huhtanen CN. Inhibition of Clostridium botulinum by Spice Extracts and Aliphatic Alcohols. J Food Prot. 1980;43:195-196.

21. Kubo I, Muroi H, Kubo A. Antibacterial activity of long-chain alcohols against Streptococcus mutans. J Agric Food Chem. 1993;41:2447-2450. 